\title{
Tubercular Mastitis Mimicking as Malignancy: A Case Report
}

\author{
Wasim Feroz ${ }^{1}$, Arwah Mohammad Ali Sheikh², Vinodkumar Mugada' \\ ${ }^{1}$ Department of Pharmacy Practice, Faculty of Pharmacy, Vignan Institute \\ of Pharmaceutical Technology, Visakhapatnam, India; \\ ${ }^{2}$ Patient Experience Management, Research Specialist, Forum Business \\ Research, Visakhapatnam, India
}

Received August 12, 2020; Accepted November 2, 2020.

Key words: Breast carcinoma - Tubercular mastitis - Fine-needle - Granuloma Tuberculosis

\begin{abstract}
Tubercular mastitis is a rare form of extrapulmonary tuberculosis commonly seen in multiparous and lactating women in developing countries. It is a diagnostic challenge and commonly misdiagnosed as breast carcinoma. Tubercular mastitis is paucibacillary, and fine-needle aspiration cytology provides an accurate diagnosis - the presence of granulomas with Langerhans giant cells on histopathological examination warrants empirical treatment with anti-tubercular drugs. We report a case of a 31-year-old Indian female who consulted a local physician with chief complaints of a palpable, tender mass in her left breast, with pain, swelling, and purulent discharge past 15 days. The patient's past medical, surgical, medication history, and family history (concerning tuberculosis) were not significant. Initially, the patient suspected of breast malignancy based upon physical examination, mammography, and fine-needle aspiration cytology but an accurate diagnosis of tubercular mastitis made with repeated histopathological examination. Histopathologic examination of excised material showed granulomas composed of histocytes, Langerhans giant cells, and inflammatory cells. The patient underwent surgical drainage on the left breast and put on the anti-tubercular regimen for 6 months with her child also prescribed isoniazid for 6 months. The patient advised for regular follow-ups.
\end{abstract}

Mailing Address: Dr. Wasim Feroz, Department of Pharmacy Practice, Faculty of Pharmacy, Vignan Institute of Pharmaceutical Technology, Visakhapatnam, India; Phone: +91 70134243 68; e-mail: wasimferoz5@gmail.com 


\section{Introduction}

Breast tuberculosis (TB), also known as tubercular mastitis (TM), is a rare form of extrapulmonary tuberculosis that was first described in 1829 by English surgeon Sir Astley Cooper (Cooper, 1829). The incidence of tubercular mastitis is $0.1 \%$ of all breast lesions in developed countries, but in developing countries where endemic is high, it reaches 3-4\% (De Sousa and Patil, 2011; Gon et al., 2013). It is common in multiparous, lactating women (Dubey and Agarwal, 1968). It presents a diagnostic challenge as it closely mimics breast carcinoma, idiopathic granulomatous mastitis, and bacterial abscesses that may result in misdiagnosis. TM is paucibacillary, and thus routine diagnostic tests used for pulmonary tuberculosis like culture, microscopy, and polymerase chain reaction (PCR) techniques are not much useful (Pai et al., 2004). Primary tuberculous mastitis particularly refers to the rare cases in which the breast tissue is infected first by tubercle bacilli (Schaefer, 1955), whereas "secondary tuberculous mastitis" refers to the presence of tuberculous co-infection elsewhere in the body (Schaefer, 1955).

Tubercular mastitis generally presents as a single breast lump in the central or upper outer quadrant due to many extensions from axillary lymph nodes to the breast. The lump is usually irregular and hard, painful, mobile, or fixed to the skin or chest wall. In some cases, the lump presented with ulceration of the overlying skin, breast abscess, nipple retraction, and breast oedema (Strazzanti et al., 2018). Fineneedle aspiration cytology (FNAC) is a beneficial technique for detecting granulomas in tuberculosis endemic countries and presence of granulomas with Langerhans giant cells in FNAC warrants empirical treatment for tuberculosis even in the absence of positive acid-fast bacilli (AFB) and culture results (Tauro et al., 2011). Mammography and breast ultrasound imaging techniques do not provide aid in the diagnosis. Antitubercular regimen for at least six months in combination with surgical drainage are usually associated with excellent outcome (Kakkar et al., 2000; Tewari and Shukla, 2005).

Following CARE guidelines, we report a rare case of tubercular mastitis in a 31-year-old female, initially suspected as a breast malignancy. However, later on, the patient was correctly diagnosed after histopathological examination of excisional biopsy material.

\section{Case report}

On $11^{\text {th }}$ May 2020, a 31-year-old Indian female, house-wife by occupation and mother of three children, consulted a local physician with chief complaints of a palpable, tender mass in her left breast, with pain, swelling and purulent discharge since past 15 days. The right breast was normal. The patient is illiterate and resides in a village. She was afebrile, and her vitals were outlined in Table 1. The patient was a non-smoker, non-alcoholic, consumes a mixed Indian diet, and has a regular sleep pattern. There was no history of loss of weight, loss of appetite, night sweats, and fever. The patient's past medical, surgical, medication history, and family history 


\section{Table 1 - Vital parameters of the patient at different periods}

\begin{tabular}{|c|c|}
\hline Date & Vital parameters \\
\hline $11^{\text {th }}$ May 2020 & $\begin{array}{l}\text { - Temperature }-36.5^{\circ} \mathrm{C} \\
\text { - Pulse rate }-96 \text { beats per minute } \\
\text { - Respiratory rate }-18 \text { breaths per minute } \\
\text { - Blood pressure }-110 / 70 \mathrm{~mm} \mathrm{Hg}\end{array}$ \\
\hline $21^{\text {st }}$ May 2020 & $\begin{array}{l}\text { - Temperature }-36.5^{\circ} \mathrm{C} \\
\text { - Pulse rate }-110 \text { beats per minute } \\
\text { - Respiratory rate }-16 \text { breaths per minute } \\
\text { - Blood pressure }-110 / 70 \mathrm{~mm} \mathrm{Hg}\end{array}$ \\
\hline $26^{\text {th }}$ May 2020 & $\begin{array}{l}\text { - Eastern Cooperative Oncology Group performance status - } 0 \\
\text { - Temperature }-36.4^{\circ} \mathrm{C} \\
\text { - Pulse rate }-112 \text { beats per minute } \\
\text { - Blood pressure }-100 / 60 \mathrm{~mm} \mathrm{Hg} \\
-\mathrm{SpO}_{2}-97 \%\end{array}$ \\
\hline $2^{\text {nd }}$ June 2020 & $\begin{array}{l}\text { - Temperature }-36.2^{\circ} \mathrm{C} \\
\text { - Pulse rate }-120 \text { beats per minute } \\
\text { - Respiratory rate }-18 \text { breaths per minute } \\
\text { - Blood pressure }-110 / 70 \mathrm{~mm} \mathrm{Hg} \\
-\mathrm{SpO}_{2}-98 \%\end{array}$ \\
\hline $3^{\text {rd }}$ June 2020 & $\begin{array}{l}\text { - Pulse rate }-80 \text { beats per minute } \\
\text { - Blood pressure }-120 / 80 \mathrm{~mm} \mathrm{Hg}\end{array}$ \\
\hline
\end{tabular}

(w.r.t. TB) were not significant. Upon physical examination, the left breast showed a painful lump with abnormal discharge.

The pharmacotherapy is outlined in Table 2. Despite the pharmacotherapy, her symptoms were not relieved. On $21^{\text {st }}$ May 2020, the patient again complained of severe pain and redness in the left breast. Upon physical examination, a painful lump with redness around the nipple area was observed. The lump was observed in the upper, anterior, and central quadrant. Her laboratory investigations and imaging technique results are outlined in Table 3. Ultrasound-guided FNAC of the left breast showed abundant inflammatory infiltrates of polymorphonuclear leucocytes, as well as several loose clusters of ductal cells seen with mild nuclear atypia along with multinucleated giant cells. Clinical differential diagnosis of ductal malignancy with abscess made. The patient referred to the National Cancer Institute $(\mathrm{NCl})$.

On $26^{\text {th }}$ May 2020, the patient visited $\mathrm{NCl}$ with severe pain and redness in the left breast, coupled with anorexia. Upon left breast examination, a lump of size measuring $6 \times 5 \mathrm{~cm}$ with nipple-areolar complex enhancement was observed. There were no signs of icterus, pallor, bleeding, pedal oedema, clubbing, and cyanosis. Her gynaecologic history was reported as G3P3A0. Her last menstrual period recorded was on $18^{\text {th }}$ May 2020, with the regular flow. The doctor advised for tru-cut biopsy, bilateral digital mammography, complete blood count (CBC), 


\section{Table 2 - Details of the pharmacotherapy at different periods}

\begin{tabular}{|c|c|c|c|}
\hline Date & Prescribed drugs & R.O.A. & Notes \\
\hline $\begin{array}{l}11^{\text {th }} \text { May } \\
2020\end{array}$ & $\begin{array}{l}\text { - Tab Amoxicillin }(500 \mathrm{mg})+\text { Clavulanic acid } \\
\text { (125 mg) - twice daily for } 5 \text { days } \\
\text { - Diethylcarbamazine citrate }-100 \mathrm{mg} \\
\text { - Piroxicam - } 10 \mathrm{mg}\end{array}$ & oral & $\begin{array}{l}\text { The treatment was } \\
\text { prescribed for } \\
\text { a one-week duration. }\end{array}$ \\
\hline $\begin{array}{l}2^{\text {nd }} \text { June } \\
2020\end{array}$ & $\begin{array}{l}\text { - Tab Amoxicillin ( } 500 \mathrm{mg})+ \text { Clavulanic acid } \\
\text { (125 mg) - twice daily for } 5 \text { days } \\
\text { - Tab Pantoprazole }(40 \mathrm{mg}) \text { - twice daily } \\
\text { for } 5 \text { days } \\
\text { - Tab Diclofenac }(50 \mathrm{mg})+\text { Serratiopeptidase } \\
\text { (10 mg) - twice daily for } 5 \text { days }\end{array}$ & oral & $\begin{array}{l}\text { The patient took } \\
\text { medicines for one day. } \\
\text { On } 3^{\text {rd }} \text { June the patient } \\
\text { was operated and was } \\
\text { prescribed with other } \\
\text { medications. }\end{array}$ \\
\hline $\begin{array}{l}3^{\text {rd }} \text { June } \\
2020\end{array}$ & $\begin{array}{l}\text { - Tab Amoxicillin }(500 \mathrm{mg})+\text { Clavulanic acid } \\
\text { (125 mg) - twice daily for } 5 \text { days } \\
\text { - Tab Paracetamol }(650 \mathrm{mg}) \text { - twice daily } \\
\text { for } 5 \text { days }\end{array}$ & oral & none \\
\hline $\begin{array}{l}11^{\text {th }} \text { June } \\
2020\end{array}$ & $\begin{array}{l}\text { Anti-tubercular regimen: } \\
\text { - Rifampicin }(\mathrm{R})-150 \mathrm{mg} \\
\text { - Isoniazid }(\mathrm{H})-75 \mathrm{mg} \\
\text { - Pyrazinamide }(\mathrm{Z})-400 \mathrm{mg} \\
\text { - Ethambutol hydrochloride (E) - } 275 \mathrm{mg}\end{array}$ & oral & $\begin{array}{l}\text { The course of treatment } \\
\text { was } 6 \text { months. The } \\
\text { child of the mother also } \\
\text { prescribed isoniazid - } \\
100 \mathrm{mg} \text {. }\end{array}$ \\
\hline
\end{tabular}

R.O.A. - route of administration

liver function test (LFT), kidney function test (KFT), CT (computed tomography) scan of chest and abdomen, and bone scan (results mentioned in Table 3). Histopathological examination of left breast mass showed breast parenchyma with epithelioid cell granulomas composed of epithelioid cells, Langerhans giant cells, central necrosis, diffuse lympho-plasmacytic chronic inflammatory infiltrates with the collection of polymorphonuclear leucocytes. Intervening areas show benign breast ducts and lobules with chronic inflammatory infiltrate. Histomorphological findings are suggestive of granulomatous mastitis. ZN (Ziehl-Neelsen) stain for AFB negative. Her bilateral digital mammography of left breast shows heterogeneously dense. It shows a large irregular lesion with serrated margins involving the upper outer and central quadrant extending to the retro-areolar region. Correlative sonomammography reported a lobulated heterogeneously hypoechoeic lesion at 2-3 o'clock position, approximately measuring $4.8 \times 2.8 \times 2.1 \mathrm{~cm}$ with retro-areolar extension. There are associated with mixed echoic collections on the lateral aspect of the nipple and medially at 9 o'clock position with mobile internal echoes, appears inflammatory/infective.

Furthermore, few prominent and enlarged left axillary lymph nodes were observed with the largest measuring $2.1 \times 1.1 \mathrm{~cm}$. Bilateral digital mammography of the left breast suggests a large irregular lesion with serrated margins involving upper, 


\section{Table 3 - Abnormal laboratory investigation and imaging technique reports of the patient}

\begin{tabular}{|c|c|c|}
\hline Date & Laboratory investigation & Imaging technique reports \\
\hline $\begin{array}{l}21^{\text {st }} \text { May } \\
2020\end{array}$ & $\begin{array}{l}\text { Fine-needle aspiration cytology: } \\
\text { The reported concluded that the } \\
\text { features are suggestive of ductal } \\
\text { malignancy with abscess. }\end{array}$ & none \\
\hline $\begin{array}{l}26^{\text {th }} \text { May } \\
2020\end{array}$ & $\begin{array}{l}\text { Haematology report: } \\
\text { - Haemoglobin }(\mathrm{Hb})-10.7 \mathrm{~g} / \mathrm{dl} \\
-\mathrm{PCV}-30.5 \% \\
-\mathrm{MCV}-69.1 \mathrm{fl} \\
-\mathrm{MCH}-24.3 \mathrm{pg} \\
\text { Histopathology report: } \\
\text { Impression: histomorphological } \\
\text { findings are suggestive } \\
\text { of granulomatous mastitis. } \\
\text { ZN stain for AFB negative }\end{array}$ & $\begin{array}{l}\text { Bilateral digital mammography: } \\
\text { Right breast: } \\
\text { Impression: bilateral digital mammography } \\
\text { reveals: } \\
\text { - No evidence of malignancy in the right } \\
\text { breast. ACR-BIRADS category } 1 . \\
\text { - Large irregular lesion with serrated margins } \\
\text { involving upper, outer and central quadrant } \\
\text { extending to the retro-areolar region as } \\
\text { described (ACR-BIRADS category } 6 \text { ). }\end{array}$ \\
\hline $\begin{array}{l}3^{\text {rd }} \text { June } \\
2020\end{array}$ & $\begin{array}{l}\text { - Random blood sugar - } 96 \mathrm{mg} / \mathrm{dl} \\
\text { - Hb - } 10.5 \mathrm{gm} / \mathrm{dl} \\
\text { - HIV screening - negative } \\
\text { - HBsAG screening - negative }\end{array}$ & none \\
\hline $\begin{array}{l}8^{\text {th }} \text { June } \\
2020\end{array}$ & $\begin{array}{l}\text { Histopathology report: } \\
\text { Left breast lump: inflammatory } \\
\text { breast pathology - granulomatous } \\
\text { mastitis. } \\
\text { There was no evidence of carcinoma } \\
\text { in the excised breast tissue. }\end{array}$ & none \\
\hline
\end{tabular}

$\mathrm{Hb}$ - haemoglobin; PCV - packed cell volume; $\mathrm{MCV}$ - mean corpuscular volume; $\mathrm{MCH}$ - mean corpuscular haemoglobin; HBsAG - hepatitis B virus antigen; ZN - Ziehl-Neelsen; AFB - acid fast bacillus

outer, and central quadrant extending to the retro-areolar region as described ACR-BIRADS category 6 (ACR-BIRADS category - Table 4; Figure 1). There was no evidence of malignancy in the right breast, and it was normal - ACR-BIRADS category 1 . The oncopathologist suggested for a repeat biopsy from the suspicious area/axillary lymph nodes for confirmation/to rule out malignancy.

On $2^{\text {nd }}$ June 2020, the results of bone scan (skeletal scintigraphy) reports came, and there was no visible evidence of osteoblastic skeletal metastasis. The CT scan of the chest and abdomen were also normal. The patient was prescribed medication, as shown in Table 2, on 2 June. She took medications for one day, and later on the other day, she was operated and advised to undergo drainage and excision of the lump in the left breast. On $3^{\text {rd }}$ June, her random blood sugar was $96 \mathrm{mg} / \mathrm{dl}$; she was tested negative for HIV screening and HBsAg screening. At 2 p.m., the patient operated on left breast under general anaesthesia, and excision 


\section{Table 4 - Concordance between BI-RADS assessment categories and likelihood of cancer}

\begin{tabular}{ll}
\hline Assessment & Likelihood of cancer \\
\hline $\begin{array}{l}\text { Category 0: Incomplete - need additional imaging } \\
\text { evaluation and prior mammograms for comparison }\end{array}$ & $\mathrm{N} / \mathrm{A}$ \\
\hline Category 1: Negative & essentially $0 \%$ likelihood of malignancy \\
\hline Category 2: Benign & essentially $0 \%$ likelihood of malignancy \\
\hline Category 3: Probably benign & $>0 \%$ but $\leq 2 \%$ likelihood of malignancy \\
\hline Category 4: Suspicious & $>2 \%$ but $<95 \%$ likelihood of malignancy \\
\hline Category 4A: Low suspicion for malignancy & $>2 \%$ to $\leq 10 \%$ likelihood of malignancy \\
\hline Category 4B: Moderate suspicion for malignancy & $>10 \%$ to $\leq 50 \%$ likelihood of malignancy \\
\hline Category 4C: High suspicion for malignancy & $>50 \%$ to $<95 \%$ likelihood of malignancy \\
\hline Category 5: Highly suggestive of malignancy & $\geq 95 \%$ likelihood of malignancy \\
\hline Category 6: Known biopsy-proven malignancy & $\mathrm{N} / \mathrm{A}$ \\
\hline N/A non a no &
\end{tabular}

N/A - not available
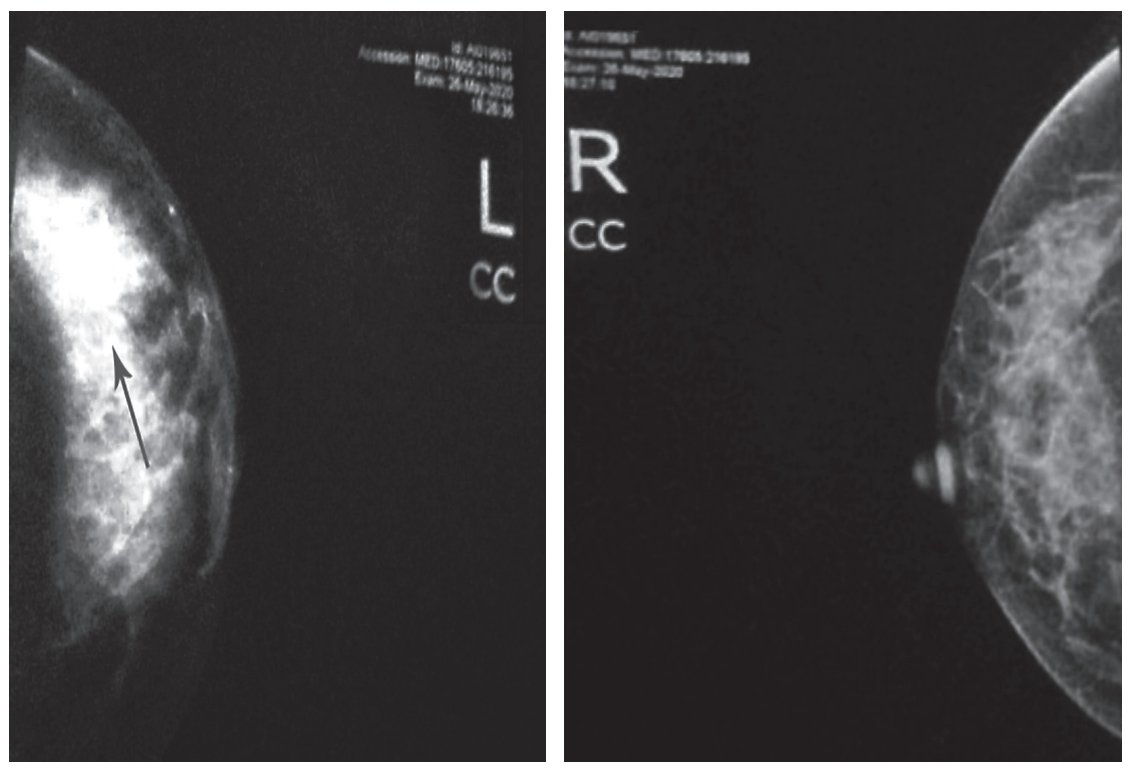

Figure 1 - Mammography of the left breast shows a large irregular lesion involving the upper, outer, and central quadrant.

with drainage performed, and the incisional biopsy material sent for testing. The patient asked to visit again after one week and prescribed medication, as outlined in Table 2. The patient referred to the regional TB hospital for further treatment. On $8^{\text {th }}$ June, the histopathological report revealed a predominantly peri-ductal 

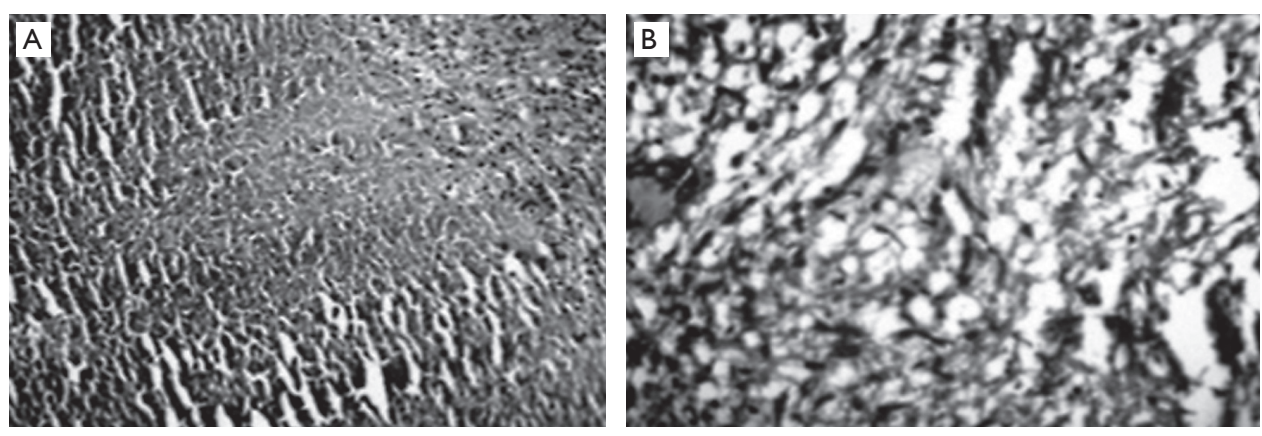

Figure 2 - A) Chronic granulomatous inflammation; B) smear confirms the presence of Langerhan's giant cell and inflammatory cells.

inflammation, peri-ductal fibrosis, and acute and chronic inflammatory infiltrate consisting of polymorphs and lymphocytes (Figure 2a). Granulomas were composed of histocytes, Langerhans giant cells, and inflammatory cells (Figure 2b), and there was no evidence of carcinoma in the excised breast tissue.

On $11^{\text {th }}$ June, the patient visited the regional TB hospital, and her weight was $45 \mathrm{~kg}$. The patient was diagnosed as tubercular mastitis (extrapulmonary TB), and the basis of diagnosis is clinical TB. She has prescribed an anti-tubercular regimen for 6 months and is advised for regular follow-ups.

ACR-BIRADS or BI-RADS stands for American College of Radiology-Breast Imaging Reporting and Data System and is established by the American College of Radiology. "BI-RADS is a scheme for putting the findings from mammogram screening (for breast cancer diagnosis) into a small number of well-defined categories" (American College of Radiology, 2020). "BI-RADS mainly benefits the radiologists who report mammograms (and breast magnetic resonance imaging and ultrasound) findings" (American College of Radiology, 2020).

\section{Discussion}

Primary tuberculous mastitis is a rare entity of TB and more commonly seen in developing countries (Madhusudhan and Gamanagatti, 2008). "Tuberculous mastitis contributes between 0.025 and $0.1 \%$ of all surgically treated breast diseases" (Kalaç et al., 2002). "Risk factors for breast tuberculosis include multiparity, lactation, trauma, history of suppurative mastitis and immunosuppression" (Tanrikulu et al., 2010). In our case, the patient had no prior history of tuberculosis, and upon physical and radiological examination, there was no evidence of any other tuberculous focus except for left breast. There is a lack of awareness about its presentation among healthcare professionals; thus, it is overlooked in the majority of the patients. The primary form of breast tuberculosis can represent tuberculous mastitis, as supported by the presence of a breast lump, which mimics breast carcinoma (Tewari and Shukla, 2005). Women of reproductive age during the 
lactation period carries a higher risk of tuberculous mastitis, and both breasts can be involved with equal frequency (Tewari and Shukla, 2005). Our patient reported to be multiparous, and only left breast was infected as confirmed by mammography and histopathological reports.

"Tuberculous mastitis may present with an irregular, painful lump in the breast (sometimes attached to the overlying skin or the underlying muscle), with or without ulceration of overlying skin and accompanied with purulent nipple discharge" (Tewari and Shukla, 2005; Biswas et al., 2018). Multiple nodules and multiple sinuses may be present, but multiple lumps are uncommon. Tenderness is more frequently seen in breast tuberculosis rather than in breast carcinomas. The upper outer quadrant of the breast is most commonly involved in breast TB. Nipple and areola are not commonly involved (Tewari and Shukla, 2005; Biswas et al., 2018). Our patient also presented with painful irregular lump with purulent nipple discharge in the left breast. The lump was observed in the upper, anterior, and central quadrant with redness around the nipple area. In our case, the patient reported no constitutional symptoms like fever, malaise, night sweats, but the patient was malnourished with a weight of around $45 \mathrm{~kg}$.

"Based on the clinical and radiological features, breast tuberculosis is classified into five different forms: nodular tuberculous mastitis, disseminated tuberculous mastitis, sclerosing tuberculous mastitis, tuberculous mastitis obliterans and acute miliary tuberculous mastitis" (McKeown and Wilkinson, 1952). "The nodulocaseous form presents as a painless, slowly growing and well-circumscribed mass that develops to involve overlying skin and may ulcerate forming discharging sinuses" (McKeown and Wilkinson, 1952). "The disseminated form initiates with numerous foci throughout the breast that caseates later, resulting in sinus formation with or without painful ulceration" (McKeown and Wilkinson, 1952). "The sclerosing form is common in the elderly, with excessive fibrosis dominating than caseation" (McKeown and Wilkinson, 1952). "Tuberculous mastitis obliterans is marked by duct infection-causing proliferation of lining epithelium with noticeable epithelial and periductal fibrosis" (McKeown and Wilkinson, 1952). "Acute miliary tuberculous mastitis is a part of generalized miliary tuberculosis" (McKeown and Wilkinson, 1952). Our case is of the nodular type. The last two forms are uncommon.

Diagnosis of breast tuberculosis is difficult, and the patients have to undertake many investigations before an accurate diagnosis. Mammograms and ultrasonography are of limited value as they do not distinguish breast tuberculosis from breast carcinoma (Tewari and Shukla, 2005). In our case, bilateral digital mammography of the right breast revealed no evidence of malignancy with ACR-BIRADS category 1. In contrast, the left breast results showed large irregular lesions in the upper, outer, and central quadrant extending to the retro-areolar region with ACR-BIRADS category 6. For correct diagnosis, bacteriological and histological examination if of high value (Bailey and Love, 1962). In TM, the bacilli isolated in only $25 \%$ of cases, and acid-fast bacilli (AFB) are detected only in $12 \%$ of the cases. In our case also, 
Ziehl-Neelsen (ZN) stain for AFB reported as negative since the disease is usually paucibacillary in most of the cases (Kakkar et al., 2000). However, for diagnosis of the disease, it is generally enough to identify the presence of caseating granulomas with Langerhans giant cells in the breast tissue, with lymph node involvement. In countries where tuberculosis is epidemic, the presence of granuloma fine-needle aspiration cytology (FNAC) is sufficient to initiate tuberculosis treatment even in the absence of positive AFB and without culture results (Tauro et al., 2011). In our case, based upon first time ultrasound-guided FNAC of the left breast clinical differential diagnosis of ductal malignancy with abscess was made. Histopathological findings for the second time revealed epithelioid cell granulomas, Langerhans giant cells, central necrosis, diffuse lympho-plasmacytic chronic inflammatory infiltrates with the collection of polymorphonuclear leucocytes. These findings suggested granulomatous mastitis. Third-time histopathological report of excisional material revealed a predominantly peri-ductal inflammation, peri-ductal fibrosis, and acute and chronic inflammatory infiltrate consisting of polymorphs and lymphocytes, granulomas composed of histocytes, giant cells, and inflammatory cells. The accurate diagnosis was made as granulomatous mastitis, and there was no evidence of carcinoma in the excised breast tissue.

There are no specific guidelines for the treatment of breast tuberculosis, but many studies have highlighted the role of anti-tubercular therapy for 6 months as the mainstay of treatment (Tewari and Shukla, 2005; Madhusudhan and Gamanagatti, 2008; Gon et al., 2013). "Anti-tuberculous therapy (ATT) includes rifampicin, isoniazid, pyrazinamide, and ethambutol" (Kao et al., 2010). Surgical drainage and resection of the ducts alone is ineffective. In our case, surgical drainage was performed, and the patient was prescribed an anti-tubercular regimen for 6 months. Along with the patient, the child of the patient has also prescribed isoniazid for 6 months. Healing is often slow, and mastectomy is restricted to patients with persistent residual infection (Bailey and Love, 1962). The patient advised for regular follow-ups.

\section{Conclusion}

Tuberculous mastitis is a rare form of extrapulmonary tuberculosis. Special care should be taken when diagnosing a breast mass, particularly in endemic areas with tuberculosis, as it may be misdiagnosed as malignancy. Histopathological examination of the excisional biopsy material provides for accurate diagnosis of the disease. Anti-tubercular regimen, surgical drainage, and regular follow-ups are the mainstays of the treatment.

\section{References}

American College of Radiology (2020) Breast Imaging Reporting and Data System. Available at: https:// www.acr.org/Clinical-Resources/Reporting-and-Data-Systems/Bi-Rads Bailey, H., Love, M. (1962) A Short Practice of Surgery. H.K. Lewis, London. 
Biswas, S. C., Banerjee, J. L., Sahu, C. R. (2018) Tuberculosis of the female breast: a case report. Biomed. J. Sci. Tech. Res. 6(5).

Cooper, A. (1829) Illustrations of the Diseases of the Breast. Printed by S. McDowall and sold by Longman, Rees, Orme, Brown and Green.

De Sousa, R., Patil, R. (2011) Breast tuberculosis or granulomatous mastitis: a diagnostic dilemma. Ann. Trop. Med. Public Health 4(2), 122.

Dubey, M. M., Agarwal, S. (1968) Tuberculosis of the breast. J. Indian Med. Assoc. 51(7), 358-359.

Gon, S., Bhattacharyya, A., Majumdar, B., Kundu, S. (2013) Tubercular mastitis - A great masquerader. Turk Patoloji Derg. 29(1), 61-63.

Kakkar, S., Kapila, K., Singh, M., Verma, K. (2000) Tuberculosis of the breast. Acta Cytol. 44(3), 292-296.

Kalaç, N., Özkan, B., Bayiz, H., Dursun, A., Demirağ, F. (2002) Breast tuberculosis. Breast 11(4), 346-349.

Kao, P. T., Tu, M. Y., Tang, S. H., Ma, H. K. (2010) Tuberculosis of the breast with erythema nodosum: a case report. J. Med. Case Rep. 4(1), 1-4.

Madhusudhan, K. S., Gamanagatti, S. (2008) Primary breast tuberculosis masquerading as carcinoma. Singapore Med. J. 49(1), e3-e5.

McKeown, K. C., Wilkinson, K. W. (1952) Tuberculous disease of the breast. Br. J. Surg. 39(157), 420-429.

Pai, M., Riley, L., Colford, J. (2004) Interferon- $\gamma$ assays in the immunodiagnosis of tuberculosis: a systematic review. Lancet Infect. Dis. 4(12), 761-776.

Schaefer, G. (1955) Tuberculosis of the breast; a review with the additional presentation of ten cases. Am. Rev. Tuberculosis Pulmonary Dis. 72(6), 810-824.

Strazzanti, A., Trovato, C., Gangi, S., Basile, F. (2018) Breast tuberculosis cases rising in Sicily. Int. J. Surg. Case Rep. 53, 9-12.

Tanrikulu, A. C., Abakay, A., Abakay, O., Kapan, M. (2010) Breast tuberculosis in Southeast Turkey: report of 27 cases. Breast Care (Basel) 5(3), 154-157.

Tauro, L. F., Martis, J. S., George, C., Kamath, A., Lobo, G., Hegde, B. R. (2011) Tuberculous mastitis presenting as breast abscess. Oman Med. J. 26(1), 53.

Tewari, M., Shukla, H. S. (2005) Breast tuberculosis: Diagnosis, clinical features and management. Indian J. Med. Res. 122(2), 103. 